\title{
Prolactin and Prolactin Receptors Are Expressed and Functioning in Human Prostate
}

\author{
Marja T. Nevalainen, ${ }^{\star}$ Eeva M. Valve, ${ }^{\star}$ Patricia M. Ingleton, ${ }^{\ddagger}$ Martti Nurmi, ${ }^{\S}$ Paula M. Martikainen, ${ }^{\|}$and Pirkko L. Härkönen* \\ *Institute of Biomedicine, Department of Anatomy and the Medicity Research Laboratory, University of Turku, FIN-20520 Turku, \\ Finland; ${ }^{\ddagger}$ Institute of Cancer Studies, University of Sheffield, Medical School, United Kingdom; ${ }^{\S}$ Department of Surgery, University of \\ Turku, FIN-20520 Turku, Finland; and ${ }^{\|}$Department of Pathology, University of Turku, FIN-20520 Turku, Finland
}

\begin{abstract}
Prolactin is widely expressed in different tissues, and it is presumed to have both local and systemic actions. In males it is known to influence reproductive functions but the significance and mechanisms of prolactin action in male accessory reproductive tissues are poorly understood. Here we show that prolactin acts as a direct growth and differentiation factor for human prostate, as measured by changes in DNA synthesis and epithelial morphology of organ cultures. Furthermore, we report the expression in human prostate of a short prolactin receptor form in addition to the long form, based upon ligand cross-linking studies and RT-PCR analysis of mRNA expression. The highest density of prolactin receptors was detected in the secretory epithelial cells by immunohistochemistry. Finally, we report that prolactin is locally produced in human prostate epithelium, as evidenced by marked prolactin immunoreactivity in a significant portion of prostate epithelial cells, with parallel expression of prolactin mRNA in human prostate. Collectively, these data provide significant support for the existence of an autocrine/paracrine loop of prolactin in the human prostate and may shed new light on the involvement of prolactin in the etiology and progression of neoplastic growth of the prostate. (J. Clin. Invest. 1997. 99:618-627.) Key words: human prostate $\cdot$ prolactin effects $\bullet$ prolactin receptors $\bullet$ prolactin expression
\end{abstract}

\section{Introduction}

Prolactin $(\operatorname{Prl})^{1}$ is a peptide hormone of numerous and distinct bioactive and immunoreactive variants (1). Its versatile functions are known to include effects on the immune system, on osmoregulation, and on behavior $(1,2)$. In reproduction Prl has been shown to have luteotropic actions and to regulate testicular function by increasing the binding of luteinizing hor-

Address correspondence to Dr. Pirkko Härkönen, Department of Anatomy, Institute of Biomedicine, University of Turku, Kiinamyllynkatu 10, FIN-20520 Turku, Finland. Phone: 358-2-3337379; FAX: 358-2-3337352; E-mail: pirkko.harkonen@utu.fi

Received for publication 13 September 1996 and accepted in revised form 3 December 1996.

1. Abbreviations used in this paper: DHT, dihydrotestosterone; $\mathrm{hPrl}$, human prolactin; M-MLV, moloney murine leukemia virus; NRS, nonimmune rabbit serum; Prl, prolactin.

J. Clin. Invest.

(C) The American Society for Clinical Investigation, Inc. 0021-9738/97/02/0618/10 \$2.00

Volume 99, Number 4, February 1997, 618-627 mone to Leydig cells $(1,2)$. Furthermore, Prl stimulates lactation and growth in mammary gland $(1,2)$ by activating the expression of milk protein genes $(3,4)$ and genes presumably necessary for proliferation of mammary cells (5-7). In prostate Prl has been presumed to have a role in the regulation of prostatic development, growth, and differentiation (8-11). Our previous results showed that in organ culture of rat dorsal and lateral prostate Prl has a direct effect on morphology, on DNA labeling with $\left[{ }^{3} \mathrm{H}\right]$ thymidine, and on the expression of prostatic tissue specific genes M-40 and RWB encoding secretory proteins (12). The dorsal and lateral lobes are the parts of rat prostate that are considered most homologous to human prostate (13). Prl has also been suggested to be involved in the regulation of abnormal prostatic function $(8,14-16)$, but little is known, however, about the specific and direct effects of Prl on human prostate. The source of Prl and the mechanisms underlying the responses of prostatic cells to Prl have remained unclear $(8,10,17-21)$.

The gene for Prl receptor (22) belongs to the cytokinehematopoietin receptor superfamily encoding receptors for growth hormone, granulocyte colony-stimulating factor, granulocyte-macrophage colony-stimulating factor, erythropoietin, leukemia inhibitory factor, oncostatin $M$, ciliary neurotrophic factor, and interleukins 2-7 (23), based on conserved sequences in their extracellular domains (24). In rat, three isoforms (short, long, and intermediate) of Prl receptor have been identified $(22,25,26)$. The short and long forms differ from each other in the length of their cytoplasmic domain resulting from alternative splicing of a single primary transcript $(22,25)$. The third rat Prl receptor, which is intermediate in size and has first been identified in the $\mathrm{Nb} 2$ pre-T rat lymphoma cell line (26), possibly $(27,28)$, results from a partial deletion in the Prl receptor gene within the cytoplasmic region of the long receptor form (26). In humans only a single Prl receptor cDNA, with a considerable homology to the rat long receptor form, has been cloned (29). However, the expression of also the intermediate form of Prl receptor in human mammary tissue, resulting from RNA processing, was reported recently (30). Of interest, only the long and intermediate receptors have been reported to be able to transduce the hormonal message to the expression of milk protein genes (4), whereas the mitogenic signal has been reported to be equally transmitted by both the long and the short Prl receptor forms (31). Receptors for Prl are widely expressed in different tissues (32-36), and extrapituitary production of Prl has been shown in lymphocytes, placenta, and mammary tissue $(30,37-42)$.

The purpose of this work was to characterize the effects of Prl on human prostatic tissue, to study its receptors, and to evaluate whether Prl is synthesized locally in human prostate. The Prl regulation of prostatic tissue was studied in organ cultures. This method was used because in primary culture normal prostatic epithelial cells frequently dedifferentiate and 
lose androgen sensitivity (43), whereas organ culture of human prostate (44) as well as rat dorsolateral $(12,36)$ and ventral prostate (45-47) has been shown to maintain hormone responsiveness and specific tissue function. This is probably due to the presence of all tissue components, which allows the interactions between epithelium and stroma, shown to be important for the maintenance of the differentiated state of prostatic epithelium $(48,49)$. The prostatic expression of Prl receptors and the local synthesis of Prl were studied at both protein and mRNA levels.

The results show that Prl has a characteristic effect on the morphology of human prostate and that it increases prostatic DNA synthesis. In this work we demonstrate, for the first time, that in addition to the long Prl receptors also the short form Prl receptors are expressed in human prostate. The Prl receptors are localized to the prostatic secretory epithelium. We also demonstrate the extrapituitary synthesis of Prl within prostate tissue which may attribute Prl a specific function as an autocrine/paracrine mediator within human prostate, in addition to its endocrine function.

\section{Methods}

Tissue samples and organ culture. Human prostate tissues were obtained from seven patients (age 39-76 yr; mean age \pm SE: 58.8 \pm 4.4 ) undergoing cystoprostatectomy because of bladder carcinoma. The tissues were used in the experiments after approval by the Local Ethical Committee. A 1-cm-thick horizontal section of each prostate tissue was transported to the laboratory in ice cold medium 199 with Earle's salts (Flow Laboratories, Newcastle, United Kingdom) supplemented with penicillin (100 IU/ml), streptomycin sulfate $(100 \mu \mathrm{l} /$ $\mathrm{ml})$, and glutamine $(100 \mu \mathrm{g} / \mathrm{ml})$. A thin slice of tissue was taken for histopathologic examination to confirm the diagnosis of each specimen, and the samples were taken for immunohistochemical stainings, membrane preparations, and mRNA determination. The rest of the prostate tissue was cultivated as explant culture which were started all within 1-3 $\mathrm{h}$ after surgery.

The organ cultures were performed as described earlier $(12,36$, 44-47). Briefly, prostatic tissue was cut into $1-\mathrm{mm}^{3}$ pieces and transferred onto lens papers lying on stainless steel grids in Petri dishes. The medium used was phenol-free medium 199 with Earle's salts (Flow Laboratories) containing dialyzed 5\% fetal calf serum, penicillin $(100 \mathrm{IU} / \mathrm{ml})$, streptomycin sulfate $(100 \mu \mathrm{l} / \mathrm{ml})$, and glutamine $(100$ $\mu \mathrm{g} / \mathrm{ml})$. The basal medium also contained the combination of insulin (insulin Lente; Novo Industries, Copenhagen, Denmark) and dexamethasone (9d-fluoro-16д-methylprednisolone; Sigma Chemical Co., St. Louis, MO) at concentrations of $0.08 \mathrm{IU} / \mathrm{ml}$ and $10^{-7} \mathrm{M}$, respectively. The gas atmosphere was a mixture of $\mathrm{O}_{2}, \mathrm{CO}_{2}$, and air (40:5: 55), and the temperature was $37^{\circ} \mathrm{C}$. The explants were cultured for $7 \mathrm{~d}$ and the medium was changed daily. Dihydrotestosterone (DHT) (5d-androstan-17 $\beta$-ol-3-one; Sigma Chemical Co.) (final concentration $10^{-7} \mathrm{M}$ ) was dissolved in ethanol. The final concentration of ethanol in the culture medium was $0.1 \%$. Human prolactin (hPrl) (a gift from Dr. Parlow, National Institute of Diabetes and Digestive and Kidney Diseases, Baltimore, MD) was diluted in $0.01 \mathrm{M} \mathrm{NaHCO}_{3}$, $\mathrm{pH} 8.0$, and used at the concentration of $45 \mathrm{nM}$, which has been proved to be suitable for the tissue culture conditions $(12,46,47)$. Four to five parallel dishes were always cultured for each hormone combination in each experiment.

Morphology. For morphological evaluation three to five explants from every dish were taken randomly in formalin at the end of the culture and embedded in paraffin. Serial sections of $7 \mu \mathrm{m}$ were cut from each piece and stained with hematoxylin and eosin.

$\left[{ }^{3} H\right]$ Thymidine incorporation and autoradiography. The incorporation of $\left[{ }^{3} \mathrm{H}\right]$ thymidine into DNA was measured at the end of each culture. The 40 explants of two Petri dishes were incubated with 2 $\mu \mathrm{Ci} / \mathrm{ml}$ methyl $\left[{ }^{3} \mathrm{H}\right]$ thymidine (Amersham, Aylesbury, United Kingdom) for $2 \mathrm{~h}$ at $37^{\circ} \mathrm{C}$ and washed thereafter with ice-cold medium to terminate the labeling reaction. 20 explants were taken for autoradiography and 20 explants were homogenized in $400 \mu$ water. The homogenate was precipitated with $20 \%$ TCA, washed three times with $5 \%$ TCA, and hydrolyzed in $5 \%$ TCA at $90^{\circ} \mathrm{C}$. The supernatant was used for DNA determination (50), and its radioactivity was measured by a liquid scintillation counter. The incorporation of radioactive thymidine into DNA is expressed as counts per minute per $100 \mu \mathrm{g}$ of DNA. The acid-soluble radioactivity was counted from the supernatant before hydrolysis of the TCA-precipitated DNA. Descriptive statistics was used to analyze the differences in DNA labeling $(\mathrm{cpm} /$ $100 \mu \mathrm{g}$ DNA) between the explants cultured with or without Prl for $7 \mathrm{~d}$. One sample $t$ test was used to analyze the difference between ratio IDP (cpm/100 $\mu \mathrm{g}$ DNA) and ID (cpm/100 $\mu \mathrm{g}$ DNA) from one. The $95 \%$ confidence interval for mean was also calculated. $P$ values $<0.05$ were interpreted as statistically significant. The statistical computations were performed using SAS program package (51).

For autoradiography, slices of the labeled explants were coated with Kodak nuclear emulsion NTB 3 after routine histologic processing. The exposure was carried out at $-15^{\circ} \mathrm{C}$ for $7 \mathrm{~d}$. The autoradiograms were developed in Kodak D19 developer and stained with hematoxylin and eosin.

Prl receptor immunohistochemistry. Human prostatic tissues were fixed in $4 \%$ formalin overnight, dehydrated, cleared, and embedded in paraffin. Sections were cut at $7 \mu \mathrm{m}$ and mounted on poly-L-lysinecoated slides. The procedure for immunohistochemical analysis of prostatic tissue is based on that of Sternberger (52) and has been described in detail by Danks et al. (53). Briefly, sections were rehydrated, nonspecific peroxidase activity was blocked by immersion in methanol-peroxide, nonspecific binding sites were blocked by normal goat serum, and sections were incubated in specific primary antibody for $2 \mathrm{~h}$ at the dilution of 1:200 at room temperature. The specific polyclonal anti-rPrl receptor antibody (R120) (36) recognizing the extracellular domain of both the short and long Prl receptors (residues 5368 of the external domain common to both receptor forms) was used. The production and use of polyclonal anti-Prl receptor antibodies has been described previously (36). After incubation with goat anti-rabbit serum (Serotec Ltd., Oxford, United Kingdom) the rabbit peroxidase-antiperoxidase (Dakopatts a/s, Copenhagen, Denmark) binding was detected using 3,3-[prime] diaminobenzidine as chromogen. For controls, primary antibody was replaced by nonimmune rabbit serum (NRS) or conjugate-absorbed serum; absorption with thyroglobulin alone did not affect specific staining. Rat kidney, human chorion leave, human breast, and rat and human female liver tissues were used as positive control tissues.

Prl immunohistochemistry. Paraffin sections $(7 \mu \mathrm{m})$ of human prostates fixed in $4 \%$ formalin were used for Prl immunohistochemistry. A polyclonal anti-hPrl antibody and biotin-streptavidin amplified immunodetection technology (both obtained from BioGenex Laboratories, San Ramon, CA) with minor modifications were used as the detection system. After deparaffination of the slides and rehydration in graded alcohol, the sections were treated with $0.4 \%$ pepsin (Merck, Darmstadt, Germany) in $0.01 \mathrm{~N} \mathrm{HCl}$ in $37^{\circ} \mathrm{C}$ to unmask the antigen epitopes. The endogenous peroxidase activity was blocked by incubating the slides in $3 \%$ peroxide in water, and the nonspecific binding of the Igs was minimized by $1 \mathrm{~h}$ of preincubation of the slides in normal goat serum (BioGenex Laboratories) at room temperature. The primary antibody was applied at a dilution of 5:100 in 1\% BSA in PBS overnight. Antigen-antibody complexes were detected by a biotinylated anti-rabbit secondary antibody and a streptavidin-biotinhorseradish-peroxidase complex with 3,3-[prime] diaminobenzidine as chromogen and Mayer hematoxylin as a counterstain. Negative controls were done either without the primary antibody or with NRS (BioGenex Laboratories). Human prolactinomas were used as positive control tissues.

Membrane preparations, iodination, and covalent cross-linking of ${ }^{125}$ I]hPrl to membrane preparations. Crude membrane fractions of 
human prostates were prepared according to the method of BenDavid et al. (54). Briefly, tissues were homogenized at four times their volume in homogenization buffer $[0.3 \mathrm{M}$ sucrose, $25 \mathrm{mM}$ Tris, $0.25 \mathrm{mM}$ PMSF, $10 \mathrm{mM}$ monothioglycerol, $1.0 \mathrm{mM}$ EGTA, $0.1 \%$ Tween 20 (Merck), and aprotinin (100,000 kallikrein inactivator units/liter)] with an Ultraturrax homogenizer (Janke \& Kunkel, IKALabortechnik, Staufen, Germany). The homogenate was centrifuged at $500 \mathrm{~g}$ for $15 \mathrm{~min}$ at $4^{\circ} \mathrm{C}$, after which the supernatant containing the crude membrane fractions was again centrifuged at $25,000 \mathrm{~g}$ for 30 $\min$ at $4^{\circ} \mathrm{C}$. The pellet was washed once with a wash buffer $[25 \mathrm{mM}$ Tris, $10 \mathrm{mM} \mathrm{MgCl}$, $1.0 \mathrm{mM}$ EGTA, $0.1 \%$ Tween $20,10 \mathrm{mM}$ monothioglycerol, $0.25 \mathrm{mM}$ PMSF, and aprotinin (100,000 kallikrein inactivator units/liter)], then resuspended in it, and used for determination of protein (55) and for receptor binding studies.

hPrl was iodinated using the IODO-GEN method (56) as described previously (36). The specific activity of labeled Prl prepared in this manner ranged from 200 to $225 \mu \mathrm{Ci} / \mu \mathrm{g}$, as determined by a self-displacement assay. The fraction of the labeled hormone derivatives capable of binding to an excess of estrogen-treated female rat liver membranes was $20-30 \%$. The binding assays were performed according to the method of Ben-David et al. (54). Briefly, $100 \mu \mathrm{g}$ of membrane proteins, pretreated with $3 \mathrm{M} \mathrm{MgCl}_{2}$ (36), and $1 \mathrm{ng}$ of [ $\left.{ }^{125} \mathrm{I}\right] \mathrm{hPrl}(300,000 \mathrm{cpm})$ were incubated in $0.5 \mathrm{ml}$ incubation buffer $\left(0.1 \% \mathrm{BSA}\right.$ in above described wash buffer) at $20^{\circ} \mathrm{C}$ for $16 \mathrm{~h}$ in the absence or presence of unlabeled hPrl $(5 \mu \mathrm{g})$. After binding equilibria were established the entire reaction mixture was centrifuged at $12,000 \mathrm{~g}$ for $4 \mathrm{~min}$ to separate the free iodine from receptor-bound $\left[{ }^{125} \mathrm{I}\right] \mathrm{hPrl}$. Freshly prepared disuccimidylsuberate in DMSO was then added to labeled membranes to a final concentration of $0.5 \mathrm{mM}$ in wash buffer. After an incubation of $15 \mathrm{~min}$ in an ice bath, ice-cold wash buffer was added to the samples to terminate the reaction, and the reaction mixture was then centrifuged at $12,000 \mathrm{~g}$ at $4^{\circ} \mathrm{C}$ for 15 min. Each pellet was then applied to a $12 \%$ vertical slab SDS polyacrylamide gel, and electrophoresis was performed according to the method of Laemmli (57) under reducing conditions (in the presence of $5 \%$ 2-mercaptoethanol and $100 \mathrm{mM} \mathrm{DTT}$ ), after which autoradiography was carried out. The experiment was repeated six times.

Northern blot analysis. RNA was isolated according to the method of Chomczynski and Sacchi (58). A PstI-EcoRV cDNA fragment (243 bp) of the rat liver Prl receptor cDNA clone $F_{3}(25,59)$ (a gift from Dr. Paul Kelly, INSERM U-344, Faculty of Medicine, Necker, Paris, France), corresponding to region unique to the short form of rat Prl receptor cDNA (see Fig. 5), was labeled by a random oligonucleotide priming method (60), and the Northern blotting and hybridization were performed as described previously (36). The experiment was repeated six times. The expression of the short Prl receptor mRNAs in liver from estrogen-treated female rats $(25,59)$ was used as a positive control (36). Furthermore, hybridization of the same filters with a human long Prl receptor probe (HindIII fragment of $\mathrm{H}_{1}$ / $\mathrm{H}_{2}$ cDNA clone) (29) was used as a reference when assessing the sizes of mRNAs for the short Prl receptor. This probe detects mRNAs of 2.8, 3.5, and $7.3 \mathrm{~kb}$ from human tissues (29).

Southern blotting. High-molecular weight DNA was isolated from human prostate samples as described previously (61). 10- $\mu \mathrm{g}$ aliquots of DNA were digested with restriction endonucleases (HindIII, EcoRI, and BamHI) at $37^{\circ} \mathrm{C}$ for $3 \mathrm{~h}$, and the digested DNA was fractionated by electrophoresis through a $1 \%$ agarose gel, denatured, and transferred to a Gene Screen Plus membrane (New England Nuclear, Boston, MA) according to the salt transfer protocol of the manufacturer. Thereafter, the membrane was treated as described before (61), and prehybridized, hybridized, and washed as described for Northern blots. A PstI-EcoRV cDNA fragment (243 bp) of the rat liver clone $\mathrm{F}_{3}$ recognizing selectively the short form Prl receptor (25, 59) (see Fig. 5) was labeled by a random oligonucleotide priming method (60). The experiment was repeated three times.

Prl receptor and Prl RT-PCR. In Prl receptor RT-PCR the sequences of primers 1 (sense primer, 917-944) and 2 (antisense primer, 1780-1805) (see Fig. 5) were 5'-ACT ATG AGG ACT TGC TGG
TGG AGT ATT T-3' and 5'-CAC TTG CTT GAT GTT GCA GTG AAG TT-3', respectively. Primers 1 and 2 were used for the amplification of a 893-bp cDNA fragment derived from the cytoplasmic domain of the long form Prl receptor mRNA (30). The sequences of primers 3 (sense primer, 607-627) and 4 (antisense primer, 903-923) (see Fig. 5) were 5'-TGC AAG CCA GAC CAT GGA TAC-3' and 5'-AGT TCC CCT GCA TTG TCC AGT-3', respectively. Primers 3 and 4 amplified a 317-bp cDNA fragment and were used to detect the short form Prl receptor mRNA (62). In Prl RT-PCR the 5'(sense) oligonucleotide primer used was 5'-GCC AGG TGT CAG CCC GGA AA-3' and $3^{\prime}$ (antisense) oligonucleotide primer was 5'-TGG GAA TCC CTG CGC AGG CA-3'. These Prl primers spanned all four introns of genomic Prl DNA and produced a fragment of 612 bp (42, $63)$ in RT-PCR. The use of all these sets of primers in both Prl receptor and Prl RT-PCR has been described previously $(30,42,62,63)$.

Total RNA extracted from T47D human breast cancer cells and from livers of estrogen-treated female rats were used as positive controls for the expression of the long (29) and short $(25,59)$ Prl receptor mRNAs, respectively. For the expression of Prl mRNA, total RNA from MCF-7 and T47D cells were used as positive controls $(30,42)$. $\mathrm{H}_{2} \mathrm{O}$ and all the samples without reverse transcriptase were used as negative controls. Total RNA from human prostates and from the positive control tissues were reverse transcribed to synthesize singlestranded cDNAs. $2 \mu \mathrm{g}$ of RNA was used as a template for cDNA synthesis. A 3'-oligo (300 ng) was added to the total RNA and was brought to a final volume of $4 \mu \mathrm{l}$ with distilled water. The samples were heated at $65^{\circ} \mathrm{C}$ for $5 \mathrm{~min}$ and were cooled slowly to room temperature. Then, $4 \mu \mathrm{l}$ of $5 \times$ moloney murine leukemia virus (M-MLV) first strand buffer, $20 \mathrm{U}$ of RNase inhibitor (Promega Corp., Madison, WI), $20 \mathrm{nmol}$ of each dNTP (Pharmacia Biotech., Uppsala, Sweden), and $100 \mathrm{U}$ of M-MLV reverse transcriptase (Promega Corp.) were added to the reaction mixture to a final volume of $20 \mu \mathrm{l}$. The tubes were heated at $37^{\circ} \mathrm{C}$ for $1 \mathrm{~h}$, and M-MLV-RT was inactivated at $99^{\circ} \mathrm{C}$ for $5 \mathrm{~min}$ after which the tubes were cooled at $5^{\circ} \mathrm{C}$ for $5 \mathrm{~min}$.

The cDNAs were amplified by 30 cycles of PCR (Perkin Elmer PCR instrument, Applied BioSystem Divisions, Foster City, CA) using each set of primers. $8 \mu \mathrm{l}$ of $10 \times$ DynaZyme buffer, $300 \mathrm{ng}$ of each primer, and sterile water were added to the $20 \mu \mathrm{l}$ of the reverse-transcribed cDNA to a final volume of $99 \mu \mathrm{l}$, after which $1 \mu \mathrm{l}(2 \mathrm{U} / \mu \mathrm{l})$ of DynaZyme (thermostable DNA polymerase from Thermus brockianus; Finnzymes Oy, Helsinki, Finland) was added to the reaction. Each cycle consisted of an incubation period of $1 \mathrm{~min}$ at $94^{\circ} \mathrm{C}, 2 \mathrm{~min}$ at $60^{\circ} \mathrm{C}$, and $2 \mathrm{~min}$ at $72^{\circ} \mathrm{C}$. The last cycle had an elongation time of $11 \mathrm{~min}$ at $72^{\circ} \mathrm{C}$.

Southern blotting of the PCR products. The PCR products of the long and short Prl receptors were transferred to GeneScreen Plus membranes (New England Nuclear) and were hybridized with a HindIII cDNA fragment ( $895 \mathrm{bp}$ ) of the $\mathrm{H}_{1} / \mathrm{H}_{2}$ human Prl receptor cDNA clone (29) and with an AvaII/RsaI cDNA fragment (440 bp) of the coding region of the rat liver Prl receptor cDNA clone $F_{3}(59)$, respectively. Also, the membrane containing the Prl RT-PCR products was hybridized with the rat Prl cDNA probe (717-bp PstI fragment of pPrl-1, a gift from Dr. R.A. Maurer) (64). The probes were labeled by a random oligonucleotide priming method (60), and the membranes were prehybridized, hybridized, and washed as described for Northern blots.

\section{Results}

The effects of Prl on the morphology of human prostate. The prostatic tissues showed involutive changes after a 7-d culture in the basal medium. Most of the epithelial cells were flattened or of metaplastic squamous type (Fig. $1 B$ ) in contrast to the columnar secretory epithelium seen in the explants before culture (Fig. $1 A$ ) or cultured with DHT (Fig. $1 C$ ). Androgen effects have been described in detail previously (44), but DHT was included in the experiments as reference for the effects of Prl. In the presence of Prl, the epithelium of the acini was strat- 

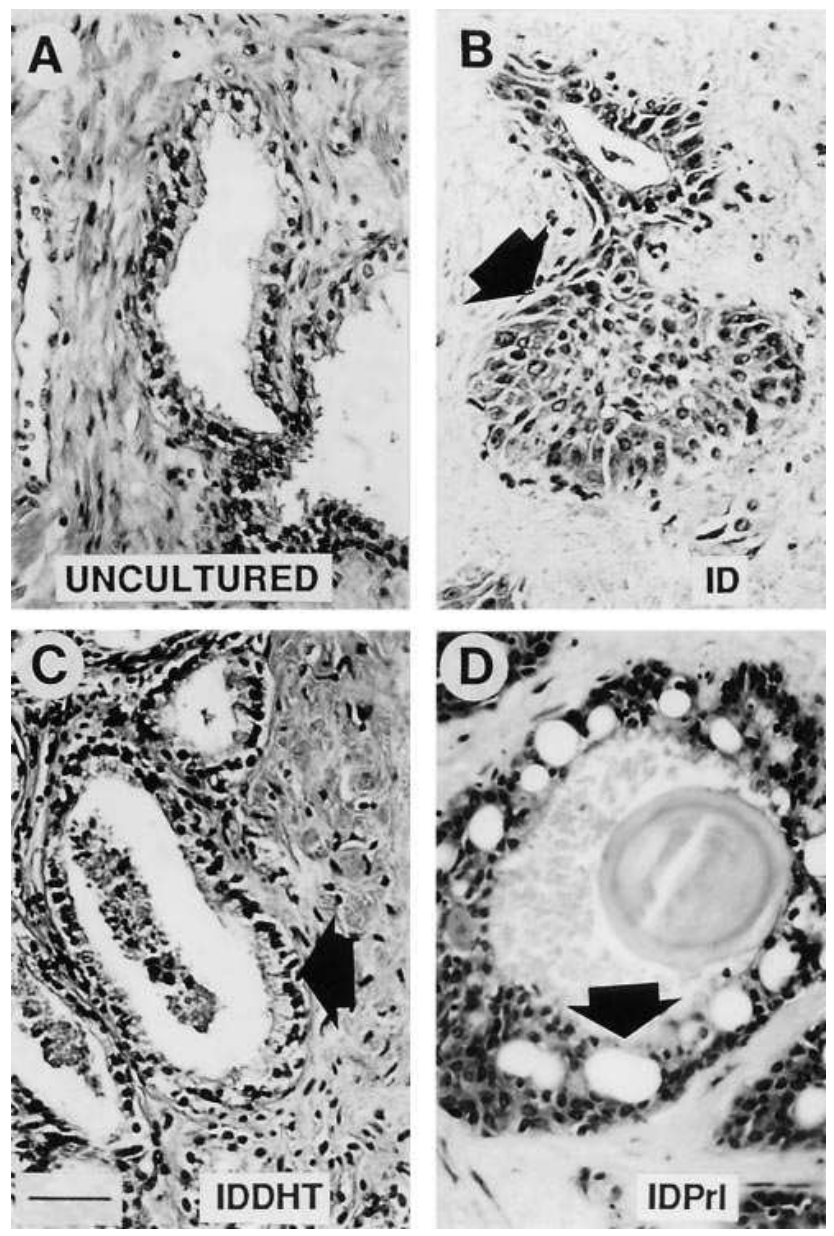

Figure 1. Morphology of human prostate cultured with Prl. Morphology of human prostate tissue before culture $(A)$ and after a 7-d organ culture in the basal medium containing insulin $(I) 0.08 \mathrm{IU} / \mathrm{ml}$ and dexamethasone $(D) 10^{-7} \mathrm{M}(B)$, with $10^{-7} \mathrm{M}$ DHT $(C)$ or with $45 \mathrm{nM}$ $\operatorname{Prl}(D) . \times 420$; bar $=24 \mu \mathrm{m}$. Arrowheads indicate squamous cell metaplasia $(B)$, maintenance of secretory epithelium in the presence of androgen $(C)$, and epithelium with microlumina when cultured with $\operatorname{Prl}(D)$.

ified, and microlumina were formed within the glandular epithelium (Fig. $1 D$ ). The epithelial cells seemed to have lost their polarized orientation in relation to the basement membrane around the acini (Fig. $1 D$ ). Also, epithelial cells had migrated to cover the surfaces of the tissue explants by two or three cell layers, and microlumina were noted also in the epithelial outgrowths.

The DNA labeling in human prostate cultured with Prl. The incorporation of tritiated thymidine into DNA was used as an index of DNA synthesis. The average increase of DNA labeling in the human prostate explants cultured with Prl was 1.79-fold $(P=0.023)$ (95\% confidence limit from 1.15 to 2.43 ) when compared with explants cultured without Prl in the basal medium (Table I). The effect of DHT on DNA labeling of human prostate tissue has been demonstrated previously (44). A 7-d culture was used, since the hormone-related changes of DNA synthesis have been shown (44) to become most evident after this organ culture period. The hormones did not affect the specific activity of $\left[{ }^{3} \mathrm{H}\right]$ thymidine as judged on the basis of the analysis of the acid-soluble fractions (data not shown).
Table I. The Level of $\left[{ }^{3} H\right]$ Thymidine Incorporation into DNA after a 7-d Organ Culture of Prostates from Seven Individual Patients

\begin{tabular}{lccc}
\hline Patient & ID* & IDPrl $^{*}$ & $\begin{array}{c}\text { Relative change } \\
\text { ID vs. IDPrl }\end{array}$ \\
\hline & & $c p m / 100 \mu g D N A^{\|}$ & \\
1 & 22982 & 59794 & 2.60 \\
2 & 36969 & 16447 & 0.44 \\
3 & 77604 & 172400 & 2.22 \\
4 & 22090 & 45555 & 2.06 \\
5 & 18705 & 37227 & 1.99 \\
6 & 32108 & 48340 & 1.55 \\
7 & 14949 & 25445 & 1.70 \\
& & &
\end{tabular}

"The incorporation of radioactive thymidine into DNA is expressed as counts per minute per $100 \mu \mathrm{g}$ of DNA. *Human prostate explants cultured in the basal medium containing $0.08 \mathrm{IU} / \mathrm{ml}$ insulin $(I)$ and $10^{-7} \mathrm{M}$ dexamethasone $(D) .{ }^{*}$ Explants cultured in the basal medium with $45 \mathrm{nM}$ Prl. ${ }^{\circledR}$ Relative change of DNA labeling (cpm/100 $\mu \mathrm{g}$ DNA) in the explants of each prostate cultured in the basal medium (ID) vs. in the basal medium with Prl (IDPrl). The average increase of DNA labeling in the explants of all seven prostates cultured with Prl was 1.79-fold $(P=0.023)(95 \%$ confidence limit from 1.15 to 2.43$)$ when compared with explants cultured in basal medium.

Autoradiographic studies showed that the labeling of DNA occurred in the epithelial cells of prostatic acini. (Fig. 2).

The expression and localization of the long and short Prl receptor proteins in human prostate. The presence of the long and a putative short Prl receptor proteins was studied by crosslinking of iodinated hPrl to membrane fractions prepared from human prostates. After cross-linking, the Prl-binding complexes were analyzed on polyacrylamide gels under reducing conditions. The prominent bands had relative molecular masses of 36,000-46,000, 60,000-70,000, and 100,000-110,000 D (Fig. 3). The apparent relative molecular masses of the labeled polypeptides minus that of iodinated $\mathrm{hPrl}\left(\sim 23,000 M_{\mathrm{r}}\right)$ are $\sim 13,000-23,000,37,000-47,000$, and 77,000-87,000 D. The appearance of $\sim 60,000-70,000$ and 100,000-110,000 $M_{\mathrm{r}}$ Prl-binding complexes was prevented by the addition of $5 \mu \mathrm{g}$ unlabeled

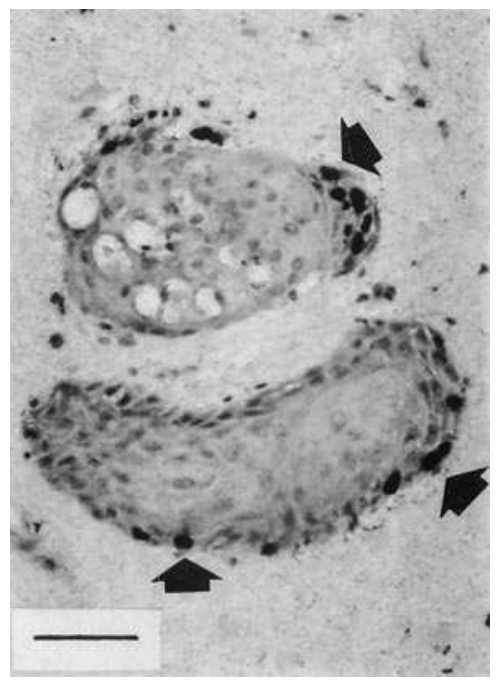

Figure 2. Autoradiography showing the localization of DNA synthesis in human prostate explants cultured with Prl. Explants of human prostates were cultured for $7 \mathrm{~d}$ in the basal medium containing $45 \mathrm{nM}$ Prl, after which the autoradiography of $\left[{ }^{3} \mathrm{H}\right]$ thymidine-labeled explants was carried out after routine histologic processing. $\times 420$; bar $=24 \mu \mathrm{m}$. 


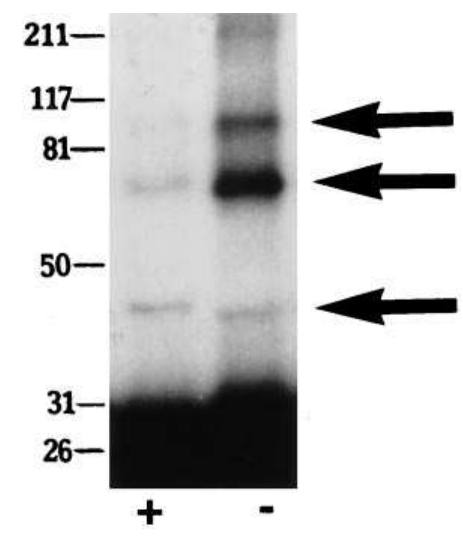

Figure 3. Cross-linking of $\left[{ }^{125} \mathrm{I}\right] \mathrm{hPrl}$ with membrane preparations of human prostate. Membrane fractions (100 $\mu \mathrm{g}$ membrane proteins) of four separate human prostates were incubated in the presence $(+)$ or in the absence $(-)$ of unlabeled hPrl $(5 \mu \mathrm{g})$ at $20^{\circ} \mathrm{C}$ for $16 \mathrm{~h}$. Cross-linking was performed with $0.5 \mathrm{mM}$ disuccimidylsuberate for $15 \mathrm{~min}$, and the samples were electrophoresed on a $12 \%$ SDSpolyacrylamide gel under reducing conditions. A representative autoradiogram of dried gels is shown. The apparent $M_{\mathrm{r}}$ of protein markers are shown on the left, and the arrows indicate the major labeled species on the right. The experiment was repeated six times.

$\mathrm{hPrl}$ in the binding reaction, whereas the $\sim 36,000-46,000 M_{\mathrm{r}}$ bands appeared despite the addition of cold ligand. Apparently, this 36,000-46,000 $M_{\mathrm{r}}$ band represents the doublet of the iodinated ligand itself, since it was also present on the control lane of electrophoresis containing only the iodinated ligand (data not shown). The Prl-binding proteins of $\sim 37,000-47,000$ and 77,000-87,000 $M_{\mathrm{r}}$ are consistent with the sizes reported for the short $\left(\sim 42,000 M_{\mathrm{r}}\right)(22,25,59)$ and for the long $(\sim 82,000$ $M_{\mathrm{r}}$ ) (29) Prl receptor proteins. When considering the possibility of multimerization of the iodinated ligand, the sizes of Prlbinding complexes of 60,000-70,000 and 100,000-110,000 $M_{\mathrm{r}}$ are not compatible with the short and long Prl receptors crosslinked with the doublet of the ligand. However, it is possible that they represent the liganded short form Prl receptor $(\sim 65,000$ $\left.M_{\mathrm{r}}\right)$ and a liganded homodimer $\left(\sim 107,000 M_{\mathrm{r}}\right)$ composed of two short Prl receptor proteins.

The localization of Prl receptor proteins in human prostatic tissue was studied by immunohistochemistry using a polyclonal anti-rPrl receptor antibody R120 (36), which recognizes both the short and long Prl receptor forms. The production of the antibody has been described previously (36). Immunohistochemical staining was localized to the secretory epithelium of human prostatic tissue (Fig. $4 A$ ) as also demonstrated in rat dorsolateral prostate (36). Especially the apical parts of the cell membranes of the prostatic secretory epithelial cells were intensively stained, whereas the basal epithelial cells did not show positive staining. There was no reaction in the sections stained with NRS (Fig. 4 B). Rat kidney, human chorion leave, human breast, and rat and human female liver were used as positive control tissues.

The expression of the long and short Prl receptor $m R N A$ s in human prostate. The expression of mRNAs for the long and short Prl receptor forms in human prostate was studied by RTPCR. The expression of the long Prl receptor mRNA was shown by using primers 1 and 2 (Fig. 5). The sequences and the use of these primers have been published previously (30). Primers 1 and 2 were used for the amplification of an 893-bp cDNA fragment of the cytoplasmic domain of the long human Prl receptor form. Consequently, the amplification of a 320-bp cDNA fragment would have revealed the presence of the putative intermediate Prl receptor (30) in human prostate, since these two receptor forms differ from each other in the length of their cytoplasmic domains $(22,25,26)$. Only an 893-bp cDNA fragment was detected from reverse-transcribed total RNA of human prostates and the control samples (Fig. $6 a$ ). This suggests that the long, but not the intermediate, Prl receptor mRNA is expressed in human prostate. Total RNA from T47D cells was used as positive control (29), and $\mathrm{H}_{2} \mathrm{O}$ and all the samples without reverse transcriptase (data not shown) were used as negative controls (Fig. 6). The long Prl receptor RT-PCR products were identified by Southern blotting and hybridization with a HindIII cDNA fragment of the $\mathrm{H}_{1} / \mathrm{H}_{2}$ human Prl receptor cDNA clone (29) (Fig. $6 b$ ).

The expression of the short Prl receptor mRNA was studied with primers 3 and 4 (Fig. 5) from the coding region of (62), and amplifying a cDNA fragment specific for, the short Prl receptor form $(59,62)$. The predicted (62) 317-bp cDNA fragment (Fig. $6 a$ ) was amplified from reverse-transcribed human prostatic total RNA. As a positive control for the short Prl receptor mRNA expression, RNA from the livers of estrogen-treated female rats was used $(22,25,59)$, and $\mathrm{H}_{2} \mathrm{O}$ and all the samples without reverse transcriptase (data not shown) were used as negative controls (Fig. 6). The short form 317-bp Prl receptor RT-PCR products were shown to correspond to the short Prl receptor cDNA by Southern blotting and hybridization with the AvaII/RsaI cDNA fragment (440 bp) from the coding region of the rat liver short Prl receptor $\mathrm{cDNA}$ clone $\mathrm{F}_{3}$ (59) (Fig. 6 b).

The sizes of mRNAs encoding the short Prl receptor in human prostates were demonstrated by Northern blotting. We prepared and used a PstI/EcoRV fragment (243 bp) of the $3^{\prime}$ untranslated region of the rat liver short Prl receptor cDNA clone $\mathrm{F}_{3}(22,25,59)$, which has been shown to recognize selectively the short Prl receptor specific mRNAs (25) (Fig. 5). From total RNA of human prostatic tissues five mRNAs of 2.8, 3.5, 4.8-5.5, 6.6-6.8, and $7.3 \mathrm{~kb}$ were detected (Fig. 7 A). The sizes of mRNAs for the short Prl receptor in human pros-
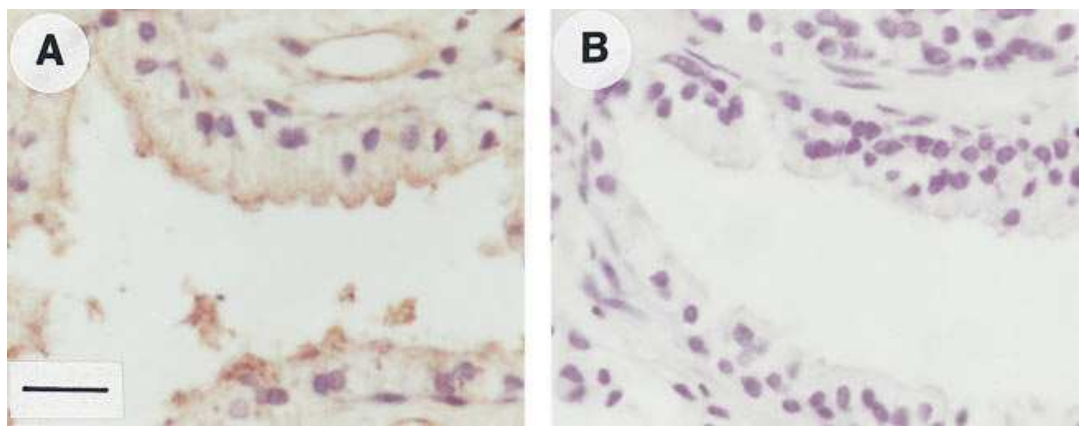

Figure 4. Immunostaining of Prl receptor in human prostate. Paraffin-embedded sections of human prostate stained with the polyclonal anti-rat Prl receptor antibody R120 $(A)$ which recognizes both the short and long Prl receptor proteins. The peroxidase-antiperoxidase method was applied to the immunostained sections counterstained with hematoxylin. Control sections $(B)$ were stained with NRS. $\times 928$; bar $=11 \mu \mathrm{m}$. 


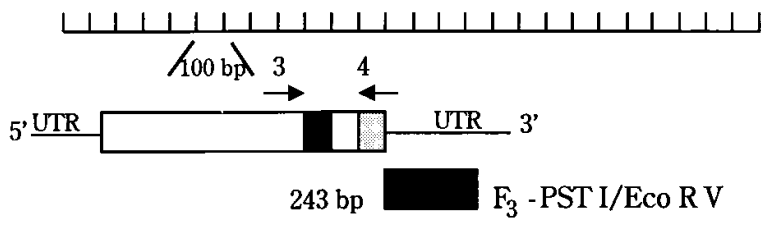

\begin{tabular}{|c|}
\hline RAT SHORT FORM \\
\hline$\left(\mathrm{F}_{3}\right.$ cDNA clone from rat liver $)$ \\
$(1635 \mathrm{bp})$
\end{tabular}

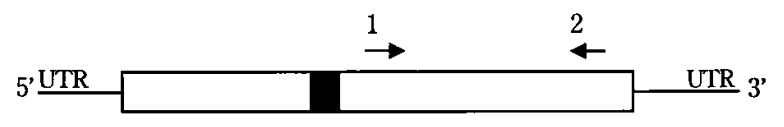

\begin{tabular}{l}
\hline HUMAN LONG FORM \\
( $\mathrm{H}_{1} / \mathrm{H}_{2}$ cDNA clone from human hepatoma) \\
(2556 bp)
\end{tabular}

Figure 5. Schematic presentation of the short and long Prl receptor cDNAs. The coding sequences are shown by boxes. The black areas are the regions encoding the transmembrane parts of the short and long Prl receptors. The dotted area is the region unique to the short form of the rat Prl receptor. The lines at the beginning and at the end of the coding regions represent the untranslated regions (UTR) contained in the cDNAs. The black box shows the location of

the fragment specific for the short Prl receptor cDNA (PstI/EcoRV 243-bp fragment of the rat liver F 3 Prl receptor clone) which was prepared and used as a cDNA probe in Northern and Southern blotting. The arrows marked with numbers indicate the positions, directions, and numbers of the primers for Prl receptor RT-PCR. Primers 1 and 2 yielded an 893-bp cDNA fragment deriving from long form Prl receptor mRNA, and primers 3 and 4 yielded a 317-bp cDNA fragment deriving from the short form Prl receptor mRNA.

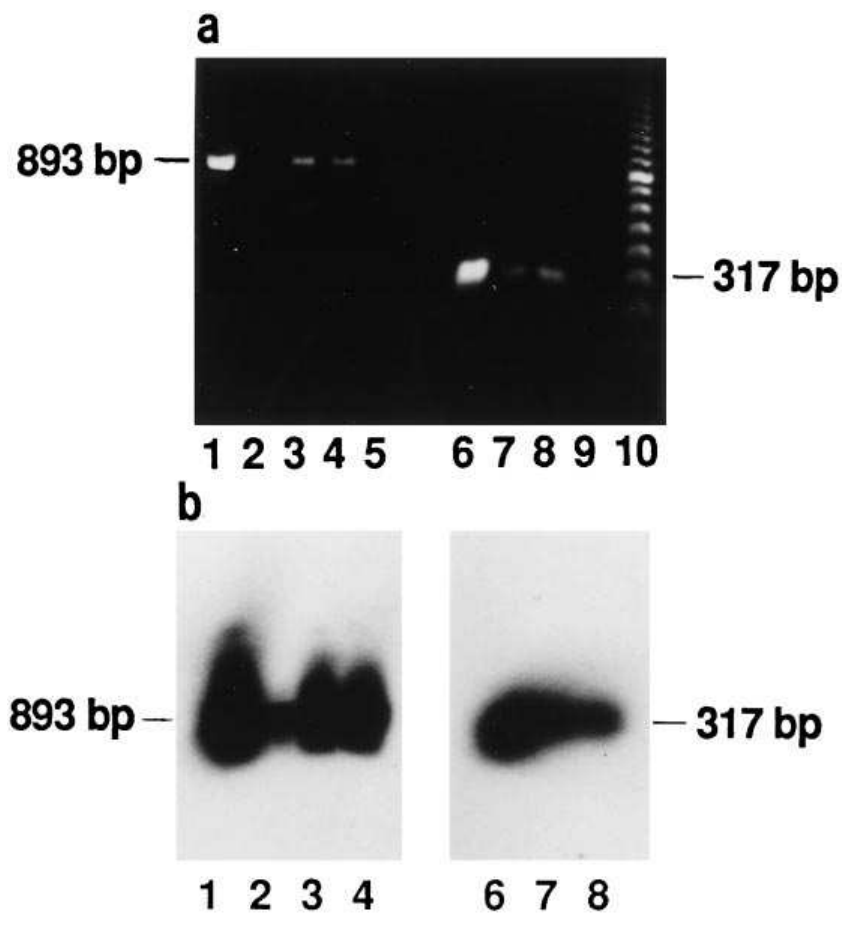

Figure 6. Demonstration of the long and short Prl receptor mRNA expression in human prostate by RT-PCR method. (a) An 893-bp fragment from the cytoplasmic domain of the long hPrl receptor and a 317-bp fragment from the coding region of the short Prl receptor were both reverse transcribed and amplified from RNA of the human prostate tissue samples. RNA from T47D breast cancer cells and from livers of estrogen-treated female rats were used as positive controls for the expression of the long and short Prl receptor mRNA expression, respectively. Lane 1 , T47D cells; lanes $2-4$, human prostates; lane $5, \mathrm{H}_{2} \mathrm{O}$; lane 6 , liver of estrogen-treated female rat; lanes 7 and 8 , human prostates; lane $9, \mathrm{H}_{2} \mathrm{O}$; lane 10,100 -bp DNA ladder. (b) The 893-bp long Prl receptor and 317-bp short Prl receptor RT-PCR products were purified, separated on agarose gels, Southern blotted, and hybridized with a HindIII cDNA fragment of the $\mathrm{H}_{1} / \mathrm{H}_{2}$ human Prl receptor cDNA clone and with an AvaII/RsaI cDNA fragment from the coding region of the rat liver Prl receptor cDNA clone $\mathrm{F}_{3}$, respectively, to show the specificities of the amplified PCR products. Lane 1, T47D cells; lanes 2-4, human prostates; lane 6 , liver from estrogen-treated female rat; lanes 7 and 8 , human prostates. The positions of 893- and 317-bp fragments of a standard are marked. tate were estimated by hybridizing the same blots with a HindIII fragment of the $\mathrm{H}_{1} / \mathrm{H}_{2}$ human long Prl receptor cDNA (29). This probe detects 2.8-, 3.5-, and 7.3-kb mRNAs in human tissues. The experiment was repeated five times. Furthermore, we observed that the PstI/EcoRV fragment (243 bp) of the rat liver $\mathrm{cDNA}$ clone $\mathrm{F}_{3}$, which was used to detect the short Prl receptor specific mRNAs (25), did not have any significant sequence similarity to other human genes described in the GenBank.

The presence of this short Prl receptor form specific sequence in the genomic DNA of human prostate was demonstrated by Southern blotting (Fig. 7 B).

The demonstration of Prl synthesis in human prostatic epithelium. The possible expression of Prl protein in human prostatic tissue was studied immunohistochemically using a polyclonal anti-hPrl antibody. The epithelium of human prostatic tissue showed an intensive cytoplasmic staining (Fig. $8 \mathrm{~A}$ ), whereas prostatic stroma was negative. The stained cells were scattered as irregular areas within the secretory epithelium. Also, staining of the basal epithelial cells was noted, especially in the areas where the prostatic epithelium was stratified in several layers. There was no reaction in the sections stained with NRS (Fig. $8 B$ ) or without the primary antibody. Human prolactinomas were used as positive control tissues.

The expression of Prl in human prostate was examined also at the mRNA level by RT-PCR, to distinguish between endogenous and exogenous Prl within human prostatic tissue. The RT-PCR reactions of human prostates produced the expected (42, 63) 612-bp band by ethidium bromide staining (Fig. 9a). The RT-PCR products were Southern blotted and hybridized with a specific hPrl cDNA probe (64) (Fig. $9 b$ ). RNA from MCF-7 and T47D breast cancer cells were used as positive controls $(30,42)$ (Fig. 9), and $\mathrm{H}_{2} \mathrm{O}$ (Fig. 9) and all the samples without reverse transcriptase (data not shown) were used as negative controls.

\section{Discussion}

In this work we demonstrate that Prl has direct effects on human prostate. The expression of Prl receptors, by which the effects of Prl are probably mediated, is also demonstrated and, furthermore, human prostatic epithelium is shown to synthe- 

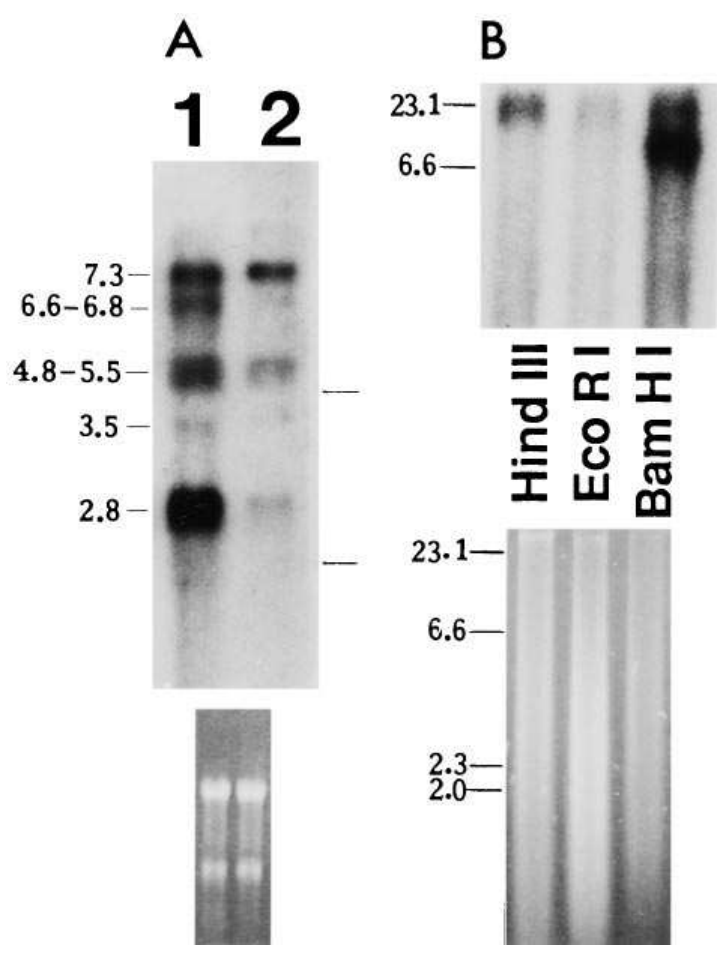

Figure 7. Northern and Southern blot analyses showing the short Prl receptor expression in human prostate. $(A)$ A representative Northern blot hybridized with a PstI/EcoRV fragment ( $243 \mathrm{bp}$ ) of the rat liver Prl receptor cDNA clone $\mathrm{F}_{3}$ detecting selectively the short Prl receptor mRNAs. $10 \mu \mathrm{g}$ of total RNA from human prostates was used. The positions of rRNAs $(18 \mathrm{~S}, 28 \mathrm{~S})$ are marked, and the corresponding ethidium bromide staining of the blot is shown to verify the loading and transfer of RNA (bottom). The experiment was repeated six times. Lanes 1 and 2, human prostates. $(B) 10 \mu \mathrm{g}$ of DNA from human prostates was digested with HindIII, EcoRI, and BamHI, fractionated on agarose gel, transferred to a nitrocellulose membrane, and hybridized with the PstI/EcoRV 243-bp fragment of the rat liver $\mathrm{F}_{3}$ Prl receptor clone showing the presence of the short Prl receptor specific sequences from human prostatic DNA. Sizes of DNA (kb) standard are shown on the left. Ethidium bromide staining of the gel is shown (bottom).

size Prl. The effects of Prl on the morphology and DNA synthesis of human prostates were investigated in organ cultures. This method was used because the function of differentiated epithelium and hormone responsiveness of both rat and human prostatic tissues have been demonstrated to be well maintained in this in vitro model $(12,36,44-47)$.

Concentration of $\operatorname{Prl}$ in the culture medium was $45 \mathrm{nM}$, which has been shown to be suitable for Prl to elicit biological responses in prostate tissue in organ culture conditions $(12,46$, $47,65,66)$. After a 7-d culture in the presence of Prl the epithelium was stratified, and round microlumina were formed irregularly within the epithelium when compared with explants cultured in the basal medium. Furthermore, the epithelial cells seemed to have lost their polarized orientation in relation to the basement membrane around the acini. These morphologic features are strikingly different from those seen in explants cultured with DHT, which have been described earlier (44) and which were used as reference for the Prl effects. Interestingly, the appearance of prostate epithelium with microlumina
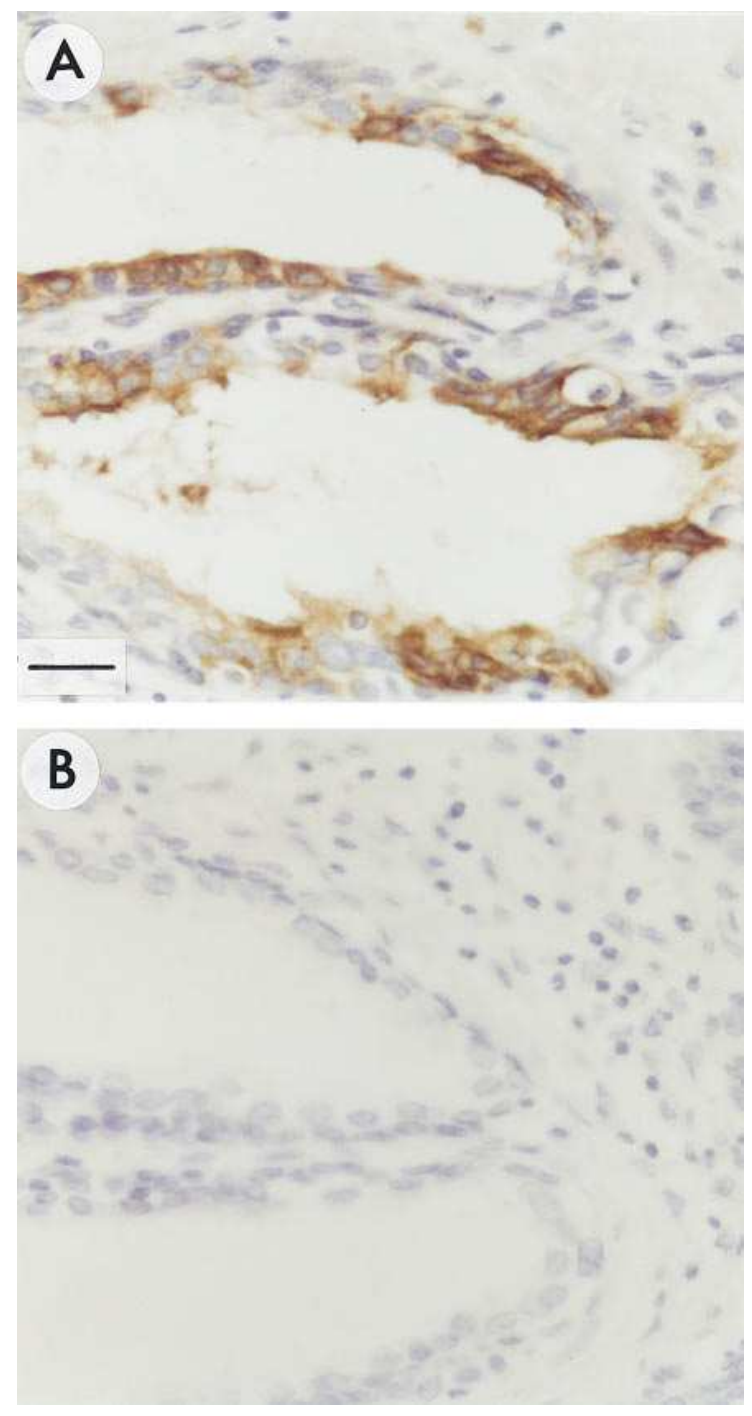

Figure 8. Immunostaining of Prl in human prostate. Paraffin-embedded sections of human prostate stained with a polyclonal anti-hPrl antibody $(A)$. The biotin-streptavidin amplified immunodetection method was applied to the sections counterstained with hematoxylin. Control sections $(B)$ were stained with NRS. $\times 1,408$; bar $=6.4 \mu \mathrm{m}$.

resembled a cribriform morphology, described as one pattern of prostatic intraepithelial neoplasia (67). It is also a common feature in in situ breast cancer (68). The level of DNA synthesis, measured by DNA labeling with tritiated thymidine, was increased on average 1.79-fold $(P=0.023)(95 \%$ confidence limit from 1.15 to 2.43) in Prl-treated explants. Although the basal level of DNA labeling was highly variable between the individuals, as also shown previously (44), the results suggest that Prl induces proliferation in human prostatic tissue. This is compatible with the results of Prl effects in rat prostate (12). The autoradiographic studies showed that the labeling of DNA occurred in the prostatic epithelium, in which also the Prl receptor proteins were shown to be located.

The finding of the expression of both the short and long Prl receptors in human prostate was interesting, since the presence of the short Prl receptor form in human tissues has not been demonstrated previously, although it has been suggested 

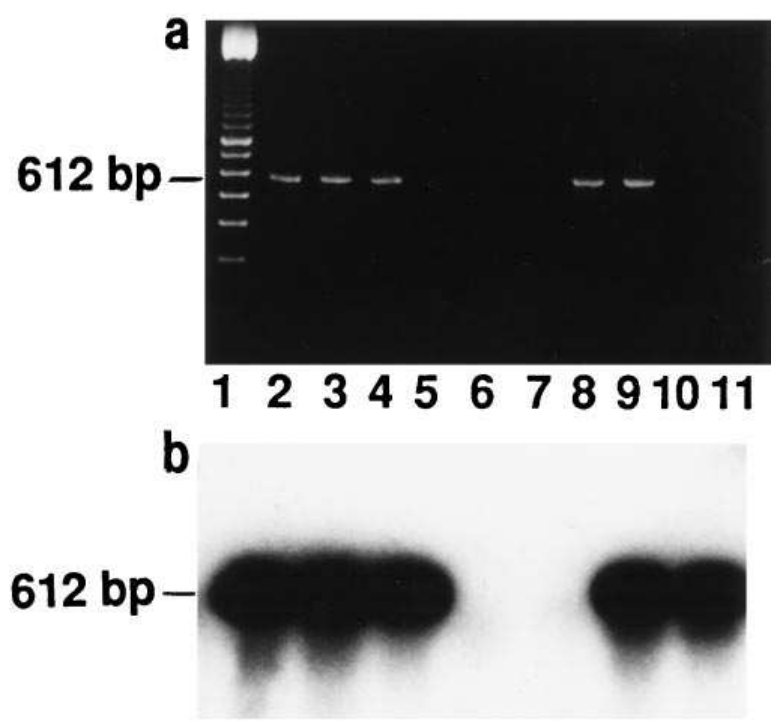

\section{$\begin{array}{llllllll}2 & 3 & 4 & 5 & 6 & 7 & 8 & 9\end{array}$}

Figure 9. Demonstration of Prl mRNA expression in human prostates by RT-PCR method. (a) A 612-bp fragment was reverse transcribed and amplified from the total RNA of the human prostate tissue samples. Total RNA from MCF-7 cells and T47D cells were used as positive controls, and $\mathrm{H}_{2} \mathrm{O}$ and all the samples without reverse transcriptase were used as negative controls. Lane 1,100-bp DNA ladder; lanes 2-4, human prostates; lanes 5-7, the same human prostate samples without reverse transcriptase; lane 8 , MCF-7 cells; lane 9, T47D cells; lane 10, MCF-7 cell RNA without reverse transcriptase; lane 11, T47D cell RNA without reverse transcriptase. (b) The 612-bp Prl RT-PCR products were purified, separated on agarose gels, Southern blotted, and hybridized with a PstII fragment of Prl cDNA to show the specificity of the amplified PCR products. Lanes 2-4, human prostates; lanes 5-7, the same human prostate samples without reverse transcriptase; lane $8, \mathrm{MCF}-7$ cells; lane 9, T47D cells. The position of a 612-bp fragment of a standard is marked ( $a$ and $b$ ).

indirectly $(30,31)$. In rat, three forms (the short, long, and the intermediate) of Prl receptor have been identified $(22,25,26)$, whereas in human tissues only the cDNA for the long Prl receptor has been cloned (29). However, in human tissues the expression of both the intermediate Prl receptor (30) and a novel splicing variant encoding only the extracellular domain of the Prl receptor protein (69) have been documented recently. We demonstrated the expression of the short and the long Prl receptors in human prostate by RT-PCR and by binding assays and subsequent cross-linking.

The Northern blot analysis of the mRNAs encoding the short Prl receptors in human prostates showed five transcripts of $2.8,3.5,4.8-5.5,6.6-6.8$, and $7.3 \mathrm{~kb}$. Interestingly, three of them $(2.8,3.5$, and $7.3 \mathrm{~kb})$ are identical with those detected with the long Prl receptor form specific probe (HindIII fragment of $\mathrm{H}_{1} / \mathrm{H}_{2}$ human long $\mathrm{Prl}$ receptor cDNA) (29). However, all of the transcripts are not necessarily translated to proteins, since total RNA was used for the analysis of the different Prl receptor mRNAs and it contains also nuclear transcripts without the $5^{\prime}$-cap-structures and poly-A-tails. In rat tissues there are several examples describing substantially small $(0.6 \mathrm{~kb})(59)$ and large $(9.5 \mathrm{~kb})$ (70) Prl receptor mRNA species that probably represent unprocessed mRNA or mRNA splicing variants with insufficient sequences to encode a complete Prl receptor protein. The functions of these mRNA species are unknown, emphasizing the role of not only transcriptional and posttranscriptional, but also translational, regulation in Prl receptor expression. A PstI/EcoRV fragment of the $3^{\prime}$ untranslated region of the rat liver short Prl receptor cDNA clone $\mathrm{F}_{3}$ was used in Northern blotting as a probe. This probe has been shown previously to specifically hybridize with the short Prl receptor specific mRNAs $(25,36)$, and we confirmed that this fragment of the short Prl receptor cDNA has no significant sequence similarity to other human genes described in the GenBank.

A single gene for Prl receptor, composed of at least 11 exons and spanning $\sim 70 \mathrm{~kb}$, has been identified in rat (22), and the 11th exon has been reported to encode the short form specific sequences, whereas the 10 th exon encodes the cytoplasmic region of the long receptor form (22). In rat the different transcripts of the long and short Prl receptors are thought to derive from the same gene (22) either by use of different initiation or polyadenylation sites or by alternative splicing of the common primary transcript $(22,25)$. So far, the structure of the human Prl receptor gene is not known, and the mechanism underlying the origin of the different transcripts for the short Prl receptor remains unclear. However, the presence of the short Prl receptor specific sequences in human prostatic genomic DNA was shown by Southern blotting with the short form specific cDNA probe used in Northern blotting. In conclusion, the results suggest that both the short and long Prl receptor mRNAs are expressed in human prostate.

The localization of Prl receptors in human prostate tissue was studied by immunohistochemistry. We used a polyclonal anti-rPrl receptor antibody R120 (36), recognizing both the short and long Prl receptors. A strong degree of sequence identity between the human Prl receptor sequence and that of the rat, particularly in this extracellular domain, has been reported (29). In human prostate the staining of Prl receptors was localized mainly to the apical parts of the secretory epithelium. The nuclei remained unstained, but faint staining was also noted in prostatic stroma. The apical staining of the secretory epithelium of human prostate, as also seen in rat dorsolateral prostate (36), is surprising since the expected localization of Prl receptors, binding circulatory Prl, would be on the basolateral cell membranes of prostatic epithelial cells. However, the basolateral cell membranes in the positive control tissues showed clear staining, and the prostatic sections were pretreated and treated in the same way as the controls. Prostatic epithelial cells are joined to each other by tight junctions, and Prl receptors located to the apical parts of the prostatic epithelial cells are not accessible to circulatory Prl. Instead, they would be accessible to a secreted ligand.

To test this hypothesis we investigated the presence of a possible autocrine and/or paracrine ligand available to these apically located Prl receptors. Indeed, a clear positive staining for Prl with the polyclonal anti-hPrl antibody was noted in prostatic epithelium. The stained cells were scattered irregularly within the prostatic epithelium, and mainly the secretory epithelial cells showed intensive staining. Conspicuously, however, in the areas where the prostatic epithelium was stratified in several layers also staining of the prostatic basal cells was often seen. The transcription of Prl gene was shown by RT-PCR using primers spanning all four introns of genomic Prl DNA and using MCF-7 and T47D cells as positive controls $(30,42)$. 
The correspondence of the expected sized $(42,63)$ 612-bp Prl RT-PCR products to the pituitary Prl was shown by Southern blotting and hybridizing the RT-PCR products with a specific hPrl cDNA probe (64).

Extrapituitary synthesis of Prl has been described in brain, placenta, and in lymphoid and mammary tissues (30, 37-42), where a local growth factor role for Prl has been suggested repeatedly $(30,37-39,41,42)$. In prostate tissue, neuroendocrine-paracrine cells, differentiated from normal prostatic epithelial cells, have been described as the third prostatic epithelial cell type and as an integral component of the normal prostatic acinar and ductal epithelium (71-74). They are known to produce a number of bioactive hormone-related substances including serotonin, chromogranin A, a thyroidstimulating hormone-like peptide, calcitonin, calcitonin generelated peptide, somatostatin, bombesin-like peptides, parathyroid hormone-related protein, and cholecystokinin (71). Moreover, the neuroendocrine differentiation has been reported to be a common feature also in nearly all prostatic adenocarcinomas (71-75), where neuroendocrine-paracrine cells have been suggested to represent an androgen receptor-negative cell reservoir harboring its own growth factor activity (71, 74). It is possible that the Prl synthesizing epithelial cells in human prostates in our study represent these neuroendocrineparacrine cells. However, the production of Prl by these cells has not been described previously (71). The local production of Prl in prostate tissue itself emphasizes the significance of Prl in the regulation of prostatic function in males. The locally produced Prl may act in an autocrine, paracrine, or even intracrine way in human prostate tissue, and it may play an important role both during growth and differentiation of prostate as well as in the secretory process of the mature gland. It may also contribute to autocrine/paracrine prostatic tumor growth factor activity.

In conclusion, our results show that Prl has a characteristic effect on the prostatic morphology and that it increases DNA synthesis in human prostatic tissue in organ culture. Both the long and short Prl receptors were demonstrated in human prostate at protein and mRNA levels. Prl receptors were located to the prostatic epithelium and their possible ligand, Prl, was also shown to be produced by the same cells. Organ cultures of human prostates provide a useful model to study the regulation and growth factor activity of locally synthesized Prl in human prostate tissue.

\section{Acknowledgments}

The National Institute of Diabetes and Digestive and Kidney Diseases National Hormone (Pituitary) Program and Dr. Parlow are gratefully acknowledged for providing polypeptide hormones. We would like to thank Dr. P. Kelly who provided the cDNA clones for $\mathrm{F}_{3}$ rat short form and for $\mathrm{H}_{1} / \mathrm{H}_{2}$ human long form Prl receptor, and Dr. R.A. Maurer (University of Iowa, Iowa City, IA) for permission to use the Prl cDNA as a probe. We want to thank Dr. T. Elsasser, Dr. H. Nikula, Dr. U. Petäjä-Repo, and Ms. A. Metsävuori for help and advice in binding assays. Also, we thank Dr. Hannu Kalimo for the control samples of Prl immunohistochemistry, Dr. Harry Kujari for the control samples of Prl receptor immunohistochemistry, Dr. Markku Kallajoki for helpful advice in Prl immunohistochemistry, and Juhani Tuominen (University of Turku), and Sakke Huhtala (Clinical Research Services, Turku, Finland) for the advice in the statistical analysis of the data. Also, we thank Ms. Merja Tasanen, Ms. Pirkko Rauhamäki, and Ms. Leena Simola for technical assistance,
Ms. Arja Karppinen for the art work, and Mr. Henrik Wikgren for preparing the photographs.

This study was financially supported by the Academy of Finland, the Cancer Societies of Finland, the Finnish Medical Foundation and Duodecim, and Cancer Society of Southwestern Finland. Dr. P.M. Ingleton received financial support from the Yorkshire Cancer Research Campaign.

\section{References}

1. Sinha, Y.N. 1995. Structural variants of prolactin: occurrence and physiological significance. Endocr. Rev. 16:354-369.

2. Wallis, M. 1988. Mechanism of action of prolactin. In Hormones and Their Actions. Part II. B.A. Cooke, R.J.B. King, and H.J. van der Molen, editors. Elsevier, Amsterdam. 295-319.

3. Guyette, W.A., R.A. Matusik, and J.M. Rosen. 1979. Prolactin-mediated transcriptional and post-transcriptional control of casein gene expression. Cell. 17:1013-1023.

4. Lesueur, L., M. Edery, S. Ali, J. Paly, P.A. Kelly, and J. Djiane. 1991. Comparison of long and short forms of the prolactin receptor on prolactin induced milk protein gene transcription. Proc. Natl. Acad. Sci. USA. 88:824-828.

5. Yu-Lee, L. 1990. Prolactin stimulates transcription of growth-related genes in Nb2 T lymphoma cells. Mol. Cell. Endocrinol. 68:21-28.

6. Stevens, A.M., and L. Yu-Lee. 1994. Multiple prolactin-responsive elements mediate $\mathrm{G} 1$ and $\mathrm{S}$ phase expression of the interferon regulatory factor-1 gene. Mol. Endocrinol. 8:345-355.

7. Clevenger, C.V., A.L. Sillman, J. Hanley-Hyde, and M.B. Prystowsky. 1992. Requirement for prolactin during cell cycle regulated gene expression in cloned T-lymphocytes. Endocrinology. 130:3216-3222.

8. Costello, L.C., and R.B. Franklin. 1994. Effects of prolactin on the prostate. Prostate. 24:162-166.

9. Reiter, E., S. Lardinois, M. Klug, B. Sente, B. Hennuy, M. Bruyninx, J. Closset, and G. Hennen. 1995. Androgen-independent effects of prolactin on the different lobes of the immature rat prostate. Mol. Cell. Endocrinol. 112: 113-122.

10. Perez-Villamil, B., E. Bordiu, and M. Puente-Cueva. 1991. Involvement of physiological prolactin levels in growth and prolactin receptor content of prostate glands and testes in developing male rats. J. Endocrinol. 132:449-459.

11. Rui, H., and K. Purvis. 1987. Prolactin selectively stimulates ornithine decarboxylase in the lateral lobe of the rat prostate. Mol. Cell. Endocrinol. 50: 89-97.

12. Nevalainen, M.T., E.M. Valve, S.I. Mäkelä, M. Bläuer, P.J. Tuohimaa, and P.L. Härkönen. 1991. Estrogen and prolactin regulation of rat dorsal and lateral prostate in organ culture. Endocrinology. 129:612-622.

13. Price, D. 1963. Comparative aspects of development and structure in the prostate. Natl. Cancer Inst. Monogr. 12:351-369.

14. Wilson, J.D. 1980. The pathogenesis of benign prostatic hyperplasia. Am. J. Med. 68:745-756.

15. Sissom, J.F., M.L. Eigenbrodt, and J.C. Porter. 1988. Anti-growth action on mouse mammary and prostate glands of a monoclonal antibody to prolactin receptor. Am. J. Pathol. 133:589-595.

16. Nakamura, A., T. Shirai, K. Ogawa, S. Wada, N.A. Fujimoto, A. Ito, and N. Ito. 1990. Promoting action of prolactin released from a grafted transplantable pituitary tumor (MtT/F84) on rat prostate carcinogenesis. Cancer Lett. 53:151-157.

17. Webber, M.M. 1981. Polypeptide hormones and the prostate. In The Prostatic Cell: Structure and Function. Part B. G.P. Murphy, A.A. Sandberg, and J.P. Karr, editors. Alan R. Liss, Inc., New York. 63-88.

18. Thomas, J.A., and M. Manadhar. 1975. Effects of prolactin and/or testosterone on nucleic acid levels in prostate glands of normal and castrated rats. J. Endocrinol. 65:149-150.

19. Walvoord, D.J., M.I. Resnick, and J.T. Grayhack. 1976. Effects of testosterone, dihydrotestosterone, estradiol, and prolactin on the weight and citric acid content of the lateral lobe of the rat prostate. Invest. Urol. 14:60-65.

20. Jones, R., P.R. Riding, and M.G. Parker. 1983. Effects of prolactin on testosterone-induced growth and protein synthesis in rat accessory sex glands. J. Endocrinol. 96:407-416.

21. Prins, G.S. 1987. Prolactin influence cytosol and nuclear androgen receptors in the ventral, dorsal, and lateral lobes of rat prostate. Endocrinology. 120:1457-1464.

22. Kelly, P.A., J. Djiane, M.C. Postel-Vinay, and M. Edery. 1991. The prolactin/growth hormone receptor family. Endocr. Rev. 12:235-251.

23. Bazan, J.F. 1990. Structural design and molecular evolution of a cytokine receptor superfamily. Proc. Natl. Acad. Sci. USA. 87:6934-6938.

24. Thoreau, E., B. Petridou, P. Kelly, J. Djiane, and J.P. Mornon. 1991. Structural symmetry of extracellular domain of the cytokine/growth hormone/ prolactin receptor family and interferon receptors revealed by hydrophobic cluster analysis. FEBS Lett. 282:26-31.

25. Shirota, M., D. Banville, S. Ali, C. Jolicoeur, J.M. Boutin, M. Edery, J. Djiane, and P.A. Kelly. 1990. Expression of two forms of prolactin receptor in 
rat ovary and liver. Mol. Endocrinol. 4:1136-1143.

26. Ali, S., I. Pellegrini, and P.A. Kelly. 1991. A prolactin-dependent immune cell line $(\mathrm{Nb} 2)$ expresses a mutant form of prolactin receptor. J. Biol. Chem. 266:20110-20117.

27. Clevenger, C.V., and M.V. Medaglia. 1994. The protein tyrosine kinase p59 $9^{\mathrm{fyn}}$ is associated with prolactin ( $\left.\mathrm{Prl}\right)$ receptor and is activated by Prl stimulation of T-lymphocytes. Mol. Endocrinol. 8:674-681.

28. Clevenger, C.V., T. Torigoe, and J.C. Reed. 1994. Prolactin induces rapid phosphorylation and activation of prolactin receptor-associated RAF-1 kinase in a T-cell line. J. Biol. Chem. 269:5559-5565.

29. Boutin, J.M., M. Edery, M. Shirota, C. Jolicoeur, L. Lesueur, S. Ali, D. Gould, J. Djiane, and P.A. Kelly. 1989. Identification of a cDNA encoding a long form of prolactin receptor in human hepatoma and breast cancer cells. Mol. Endocrinol. 3:1455-1461.

30. Clevenger, C.V., W.P. Chang, W. Ngo, T.L.M. Pasha, K.T. Montone, and J.E. Tomaszewski. 1995. Expression of prolactin and prolactin receptor in human breast carcinoma; evidence for an autocrine/paracrine loop. Am. J. Pathol. 146:695-705.

31. Das, R., and B.K. Vonderhaar. 1995. Transduction of prolactin's growth signal through both long and short forms of the prolactin receptor. Mol. Endocrinol. 9:1750-1759.

32. Nagano, M., and P.A. Kelly. 1994. Tissue distribution and regulation of rat prolactin receptor gene expression. J. Biol. Chem. 269:13337-13345.

33. Ouhtit, A., G. Morel, and P.A. Kelly. 1993. Visualization of gene expression of short and long forms of prolactin receptor in rat reproductive tissues. Biol. Reprod. 49:528-536.

34. Ouhtit, A., P.A. Kelly, and G. Morel. 1994. Visualization of gene expression of short and long forms of prolactin receptor in rat digestive tissues. Am. J. Physiol. 266:G807-G815.

35. Lobie, P.E., J. Garcia-Aragon, and M.J. Waters. 1993. Prolactin receptor expression in the gastrointestinal tract: characterization of the prolactin receptor of gastric mucosa. J. Endocrinol. 139:371-381.

36. Nevalainen, M.T., E.M. Valve, P.M. Ingleton, and P.L. Härkönen. 1996. Expression and hormone regulation of prolactin receptors in rat dorsal and lateral prostate. Endocrinology. 137:3078-3088.

37. Sabharwal, P., R. Glaser, W. Lafuse, S. Varma, Q. Liu, S. Arkins, R. Kooijman, L. Kutz, K.W. Kelley, and W.B. Malarkey. 1992. Prolactin synthesized and secreted by human peripheral mononuclear cells: an autocrine growth factor for lymphoproliferation. Proc. Natl. Acad. Sci. USA. 89:7713-7716.

38. Hooghe, R., M. Delhase, P. Vergani, A. Malur, and E.L. Hooghe-Peters. 1993. Growth hormone and prolactin are paracrine growth and differentiation factors in the haemopoietic system. Immunol. Today. 14:212-214.

39. Wu, H., R. Devi, and W. Malarkey. 1996. Expression and localization of prolactin messenger ribonucleic acid in the human immune system. Endocrinology. 137:349-353.

40. Handwerger, S., R.G. Richards, and E. Markoff. 1992. The physiology of decidual prolactin and other decidual protein hormones. Trends Endocrinol. Metab. 3:91-95.

41. Mershon, J., W. Sali, N. Mitchner, and N. Ben-Jonathan. 1995. Prolactin is a local growth factor in rat mammary tumors. Endocrinology. 136:3619-3623.

42. Ginsburg, E., and B.K. Vonderhaar. 1995. Prolactin synthesis and secretion by human breast cancer cells. Cancer Res. 55:2591-2595.

43. McKeehan, W.L., P.S. Adams, and D. Fast. 1987. Different hormonal requirements for androgen-independent growth of normal and tumor epithelial cells from rat prostate. In Vitro Cell. Dev. Biol. 23:147-152.

44. Nevalainen, M.T., E.M. Valve, W. Ping, M. Nurmi, P.L. Härkönen, and P.M. Martikainen. 1993. Hormone regulation of human prostate in organ culture. Cancer Res. 53:5199-5207.

45. Martikainen, P.M., P.L. Härkönen, T. Vanhala, S.I. Mäkelä, M. Viljanen, and J.J.O. Suominen. 1987. Multihormonal control of synthesis and secretion of prostatein in cultured rat ventral prostate. Endocrinology. 121:604611.

46. Martikainen, P. 1987. Maintenance of adult rat ventral prostate in organ culture. Anat. Rec. 218:166-174.

47. Johansson, R. 1975. RNA, protein and DNA synthesis stimulated by testosterone, insulin and prolactin in the rat ventral prostate cultured in chemically defined medium. Acta Endocrinol. 80:761-764

48. Chang, S.M., and L.W.K. Chung. 1989. Interaction between prostatic fibroblasts and epithelial cells in culture: role of androgen. Endocrinology. 125: 2719-2727.

49. Cunha, G.R., N. Hayashi, and Y.C. Wong. 1991. Regulation of differentiation and growth of normal adult and neoplastic epithelia by inductive mesenchyme. In Prostate Cancer. L.M. Franks and J.T. Isaacs, editors. Cold Spring Harbor Laboratory Press. Cancer Surveys. 11:73-89.

50. Burton, K. 1956. A study of the conditions and mechanisms of the diphenylamine reaction for the colorimetric estimation of deoxyribonucleic acid. Biochem. J. 62:315-323.

51. SAS Institute Inc. 1990. SAS/STAT Users Guide, Version 6, 4th Edition, Vols. 1 and 2. SAS Institute Inc., Cary, NC.

52. Sternberger, L.A. 1974. Immunocytochemistry. Prentice-Hall, Englewood Cliffs, NJ.

53. Danks, J.A., A.J. Devlin, P.M.W. Ho, H. Diefenbach-Jagger, D.M. Power, A.V.M. Canario, T.J. Martin, and P.M. Ingleton. 1993. Parathyroid hormone-related protein is a factor in normal fish pituitary. Gen. Comp. Endocrinol. 92:201-212.

54. Ben-David, M., T. Kadar, and A.V. Schally. 1986. Micromethod for the determination of free and total prolactin receptors: measurement of recepto levels in normal and malignant mammary and prostate tissues. Proc. Natl. Acad. Sci. USA. 83:8375-8379.

55. Bradford, M.M. 1976. A rapid and sensitive method for the quantitation of microgram quantities of protein utilizing the principle of protein-dye binding. Anal. Biochem. 72:248-254.

56. Salacinski, P.R.P., C. McLean, J.E.C. Sykes, V.V. Clement-Jones, and P.J. Lowry. 1981. Iodination of proteins, glycoproteins, and peptides using a solid-phase oxidizing agent, 1,3,4,6-tetrachloro-3a,6a-dipenyl glycoluril (IODOGEN $^{\circledR}$ ). Anal. Biochem. 117:136-146.

57. Laemmli, U.K. 1970. Cleavage of structural proteins during assembly of the head of bacteriophage $\mathrm{T}_{4}$. Nature (Lond.). 227:680-685.

58. Chomczynski, P., and N. Sacchi. 1987. Single-step method of RNA isolation by acid guanidinium thiocyanate-phenol-chloroform extraction. Anal. Biochem. 162:156-159.

59. Boutin, J.M., C. Jolicoeur, H. Okamura, J. Gagnon, M. Edery, M. Shirota, D. Banville, I. Dusanter-Fourt, J. Djiane, and P.A. Kelly. 1988. Cloning and expression of the rat prolactin receptor, a member of the growth hormone/ prolactin receptor gene family. Cell. 53:69-77.

60. Feinberg, A.P., and B. Vogelstein. 1983. A technique for radiolabeling DNA restriction endonuclease fragments to high specific activity. Anal. Biochem. 132:6-13.

61. Mellanen, P., H. Minn, R. Grenman, and P. Härkönen. 1994. Expression of glucose transporters in head-and-neck tumors. Int. J. Cancer. 56:622-629.

62. Sakaguchi, K., T. Ohkubo, M. Tanaka, H. Ushiro, and K. Nakashima. 1994. Differential regulation of prolactin receptor mRNA expression in rat liver and kidney by testosterone and oestradiol. J. Endocrinol. 143:383-392.

63. Fields, K., E. Kulig, and R.V. Lloyd. 1993. Detection of prolactin messenger RNA in mammary and other normal and neoplastic tissues by polymerase chain reaction. Lab. Invest. 68:354-359.

64. Gubbins, E.J., R.A. Maurer, M. Lagrimini, C.R. Erwin, and J.E. Donelson. 1980. Structure of the rat prolactin gene. J. Biol. Chem. 255:8655-8662.

65. Rui, H., I. Brekke, P.A. Torjesen, and K. Purvis. 1986. Homologous upregulation of the prolactin receptor in rat prostatic explants. Mol. Cell. Endocrinol. 46:53-57.

66. Franklin, R.B., and L.C. Costello. 1990. Prolactin directly stimulates citrate production and mitochondrial aspartate aminotransferase of prostate epithelial cells. Prostate. 17:13-18.

67. Bostwick, D.G., M.B. Amin, P. Dundore, W. Marsh, and D.S. Schultz. 1993. Architectural patterns of high-grade prostatic intraepithelial neoplasia. Hum. Pathol. 24:298-310.

68. Page, D.L., T.J. Anderson, and L.W. Rogers. 1987. Carcinoma in situ (CIS). In Diagnostic Histopathology of the Breast. D.L. Page and T.J. Anderson, editors. Churchill Livingstone, Edinburgh-London-Melbourne-New York. 158-171.

69. Fuh, G., and J.A. Wells. 1995. Prolactin receptor antagonists that inhibit the growth of breast cancer cell lines. J. Biol. Chem. 270:13133-13137.

70. Hu, Z.Z., and M. Dufau. 1991. Multiple and differential regulation of ovarian prolactin receptor messenger RNAs and their expression. Biochem. Biophys. Res. Commun. 181:219-225.

71. Abrahamssom, P.-A. 1996. Neuroendocrine differentiation and hormone-refractory prostate cancer. Prostate. 6:3-8.

72. Bonkhoff, H., U. Stein, and K. Remberger. 1995. Endocrine-paracrine cell types in the prostate and prostatic adenocarcinoma are postmitotic cells. Hum. Pathol. 26:167-170.

73. Aprikian, A.G., C. Cordon-Cardo, W.R. Fair, and V.E. Reuter. 1993 Characterization of neuroendocrine differentiation in human benign prostate and prostatic adenocarcinoma. Cancer (Phila.). 71:3952-3965.

74. Bonkhoff, H., U. Stein, and K. Remberger. 1993. Androgen receptor status in endocrine-paracrine cell types of the normal, hyperplastic, and neoplastic human prostate. Virchows Archiv. A Pathol. Anat. 423:291-294.

75. Santágnese, P.A. 1992. Neuroendocrine differentiation in human prostatic carcinoma. Hum. Pathol. 23:287-296. 